Bioscientia Medicina: Journal of Biomedicine \&

Translational Research

Journal Homepage: www.bioscmed.com

\title{
The Effect of Ethynil Estradiol and Desogestrel on Proliferation and Apoptosis Hydatidiform Mole Trophoblast Cell
}

\author{
Irawan Sastradinata ${ }^{*}$, Andrijono ${ }^{2}$, Mohamad Farid Aziz ${ }^{2}$, Wan Lelly H $^{3}$, Sri Hartini ${ }^{3}$, Bambang \\ Sutrisna 4 \\ ${ }^{1}$ Departement of Obsttrics and Gynecology Medical Faculty of Sriwijaya University Palembang Indonesia. \\ ${ }^{2}$ Division of Oncology Departement of Obsttrics and Gynecology Dr. Cipto Mangunkusumo General Hospital Jakarta Indonesia. \\ ${ }^{3}$ Dharmais Cancer Center Hospital Jakarta Indonesia \\ ${ }^{4}$ Community Medicine Faculty University of Indonesia
}

\section{A R T I C L E I N F O \\ Keywords: \\ Hydatidiform mole \\ Trophoblas \\ Proliferation \\ Apoptosis \\ Ethynil estradiol \\ Desogestrel \\ *Corresponding author: \\ Irawan Sastradinata \\ E-mail address: \\ wansastra@yahoo.com}

All authors have reviewed and approved the final version of the manuscript.

\section{https://doi.org/10.32539/bsm.v5i4.223}

\begin{abstract}
A B S T R A C T
Background: To explore the effect of ethynil estradiol and desogestrel on proliferation and apoptosis hydatidiform mole trophoblast cell. Methods: From April 2008 until March 2009, we collected 15 samples of hydatidiform mole tissue. Trophoblast cells was isolated and culture at RPMI 20\% FBS medium. Only 7 samples $(46 \%)$ shown good growth. Cell was identified using cytology and $\beta$ HCG test. Trophoblast cells good quality than devided into three groups observation. First group get ethynil estradiol $10 \mathrm{nmol} / \mathrm{mL}$, second group get desogestrel $100 \mathrm{nmol} / \mathrm{mL}$, Third group get DMSO 1\%. Cells incubated and observe at 24, 48, 72, 96 hours. Cell cycle, apoptosis and $\beta$ HCG was evaluated at each time observation. Cell cycle evaluation using BD cycle test plus DNA reagent, apoptosis evaluation using FITCAnnexin V. Analyze using FACSCalibur flowcytometer. $\beta$ HCG evaluation using Abbott AxSym total $\beta$-HCG reagent pack. Results: The group of cell that get ethynil estradiol in concentration $10 \mathrm{nmol} / \mathrm{mL}$ had cell proliferation index, amount cells and $\beta$ HCG level higher than control after 72 hours observation. The group of cell that get desogestrel in concentration $100 \mathrm{nmol} / \mathrm{mL}$ have cell proliferation index, amount cells and $\beta$ HCG level lower than control after 48 hours observation. There are no differences of apoptosis between the two group and control. Conclusion: Ethynil estradiol will increase proliferation of hydatidiform mole trophoblast cell, while desogestrel will decrease proliferation of hydatidiform mole trophoblast cell. There are no effect of ethynil estradiol and desogestrel on apoptosis of hydatidiform mole trophoblast cell.
\end{abstract}

\section{Introduction}

Hydatidiform Mole is an abnormal pregnancy that is characterized histologically by proliferation of trophoblast cell, avascularity and hydropic degenaration of the chorionic villi [1]. The incidence rates of Molar pregnancies (hydatidiform mole) is still high in Asia. In Indonesia, it's occurs about 1 out of every $47(1 / 47)$ deliveries until 1 out of every 427 (1/427) deliveries. Molar pregnancies can become cancerous recognized as Malignant Trophoblastic Disease (MTD). The incidence rates of MTD between
$15 \%$ and $28 \%[2-4]$. Factors that contribute to the malignancy after hydatidiform mole are: DNA abnormalities, oncogenes, tumor suppressor genes, nutrition and hormonal status, including steroid hormones such as estrogen and progesterone [5].

The use of hormonal contraception in Indonesia is still high, no exception in post-molar pregnancy. The recomendation to use oral contraception for trophoblast patients is only for the patient who have normal $\beta-\mathrm{HCG}$ on laboratory examination [6-8]. 
Oral contraception (OC) can be a risk factor but also be a protective factor for some gynecology cancer. OC are the risk factor for cervical cancer and breast cancer, but OC are the protective factor for ovarian cancer and endometrial cancer. The protective effect of course because of OC are contain progesterone hormon [9].

Estrogen hormone shown an important rule for the carcinogenesis in breast cancer, endometrial cancer, liver cancer and some other cancers. This is because estrogen through estrogen receptor pathway may increase the activity of cell proliferation. In addition, some carcinogenic metabolites product of estrogen alone can cause DNA abnormalities. Estrogen can also decrease apoptosis and it will be additional risk for develop cancer. The role of progesterone in carcinogenesis have some different activity. Progesterone can induce proliferation and also inhibited proliferation depending on the type of organs and cell types.

It well known that apoptosis and proliferation are two things that play a role in carcinogenesis. The balancing of both effect on proliferation and apoptosis are important on carcinogenesis of gynecologic patients [10-14].

One of the questions that until now still discussed are; how the risk of cancer for post molar patient who use hormonal contraception. The absence of both in vitro and in vivo study on the effects of estrogen and progesterone on hydatidiform mole trophoblast cell is the background of this study. This study will try to know the role of ethinyl estradiol and desogestrel in proliferation and apoptosis hydatidiformmole trophoblast cells.

\section{Materials and Methods}

This is an experimental study that examine the proliferation and apoptosis effect of ethynil estradiol and desogestrel on hydatidiform mole trophoblast cells. From April 2008 until March 2009 we collected 15 samples hydatidiform mole tissue from curretage and hysterectomy. Trophoblast cells was isolated from molar tissue and then cultured at medium RPMI sulemented with $20 \%$ fetal bovine serum (FBS), in $5 \%$
$\mathrm{CO}_{2}$ at $37 \circ \mathrm{C}$. Only 7 samples (46\%) shown good growth. The quality of trophoblast cells indentified by Papanicolaou staining and cytology examination. Cytotrophoblast and sincitio trophoblast was able identified from good quality of trophoblast cells culture. The level $\beta$-HCG of medium culture supernatant also measured. Trophoblast cells culture produce $\beta$-HCG and was able measured. The Number of cells also measured. Cells amount more than $1 \times 105 / \mathrm{mL}$ are good qulity. Trophoblast cells culture good quality will include in experiment.

Ethynil estradiol and desogestrel was obtained from PT Sydna Pharma (Organon Indonesia), as raw material for Marvelon oral pill contraceptive.

The treatment given to the samples and the control as follow:

1. Preparation wells

- Well 1 (A,B,C,D) ethynil estradiol group

- Well 2 (A,B,C,D) desogestrel group

- Well 3 (A,B,C,D) control group

2. Treatment

- Well 1 (A,B,C,D) get treatment ethinyl estradiol $10 \mathrm{nmol} / \mathrm{mL}$

- Well 2 (A,B,C,D) get treatment desogestrel 100 $\mathrm{nmol} / \mathrm{mL}$

- Well 3 (A,B,C,D) get treatment DMSO 1\%

3. Each wells (A) incubate for 24 hours, each wells (B) incubate for 48 hours, each wells (C) incubate for 72 hours and each wells (D) incubate for 96 hours.

4. Number of cells was calculated. The pellet of cells was diluted with a solution tripane blue, only live cell can be seen and counted. cell then count using Haemocytometer. The cells concentration more than $1 \mathrm{x} 106 / \mathrm{mL}$ prepared for analysis.

5. Each culture cells was done examination as follow:

- The number of cells

- $\beta$ HCG supernatant examination

- Propidium iodide staining and cell cycle examination using flow cytometer 
- FITC-Annexin V staining and apoptosis examination using flow cytometer.

6. The $\beta$-HCG examination using Abbott AxSym total $\beta-$ HCG reagent pack [15].

7. Cell cycle examination using BD Cycletest ${ }^{\mathrm{TM}}$ Plus DNA Reagent Kit. Cells were washed and staining according to the manufacturer's protocol. Reading with FACSCalibur flow cytometer and verity soft ware ModfitLt 3.0, ModfitLt 3.2 [16].

8. Apoptosis examination using the Annexin V-FITC apoptosis detection kit (BD Pharmigen, San Diego, CA, USA). Cells were washed and staining Annexin V-FITC and propidium iodide (PI) according to the manufacturer's protocol. reading with FACSCalibur flowcytometer and software Cell Quest 5.1 [1].

\section{Results}

The number of cell was counted as a routine procedure prior flowcytometer examination. using solution tripane blue, only live cell can be counted.

In ethynil estradiol group, the amount of cells more than control group at 72 hours to 96 hours observation, while desogestrel group less than control at 24 hours to 96 hours examination. It's shown that ethynil estradiol will increased cell division and it's significantly evident since 72 hours cells was incubated and also shown that desogestrel will inhibited cell division since 24 hours cells was incubated.

Cell cycle analysis at flow cytometry will give information about persentage of cells on each phase cell division. Specifically group cells in G0/G1 phase, group cell in $\mathrm{S}$ phase, and group cell in G2/M phase

Proliferation index calculated base on formula: Proliferation index $(\mathrm{PI})=(\mathrm{G} 2 / \mathrm{M}+\mathrm{S}) \div(\mathrm{G} 0 / \mathrm{G} 1+\mathrm{S}+$ G2/M) x 100\% [17].
The proliferation index of trophoblast cells as follow.

The proliferation index of ethynil estradiol group is higher than the control group at 48 hours to 96 hours observation, while in the group of desogestrel the proliferation index lower than the control group at 48 hours to 96 hours observation. It's shown that ethynil estradiol will increased cell proliferation and it's significantly evident since 48 hours cells was incubated and also shown that desogestrel significantly will inhibited cell proliferation since 48 hours cells was incubated.

The level of $\beta$-HCG examined with microparticle enzym immuno assay using monoclonal/ poiclonal anti $\beta$-HCG reagent Abbott AxSym. The result of $\beta-\mathrm{HCG}$ level in each groups as follow.

The ethynil estradiol group shown $\beta$-HCG supernatant higher than control at 72 hour to 96 hours observation. In contrast with desogestrel group that $\beta$ HCG level less than control at 24 hour to 96 hours observation.

On examination apotosis that staining with FITCAnnexin V, reading use FACSCalibur flowcytometer, we get the percentage of cells that are in the early phase of apoptosis, percentage of cell in advance phase of apoptosis and early necrosis. The result of apoptosis as follow.

In the group ethynil estradiol apoptosis lower than control at 72 hours and apoptosis higher than control at 24, 48, 96 hours observation. In the group desogestrel the apoptosis lower than control at 72 hours and 96 hours, while apoptosis higher than control at 24 hours and 48 hours observation.

The result above cannot give consistent result of the effect of ethynil estradiol and desogestrel on apoptosis of trophoblast cells, so in this study we didn't find any effect of ethynil estradiol and desogestrel on apoptosis of trophoblast cells. 


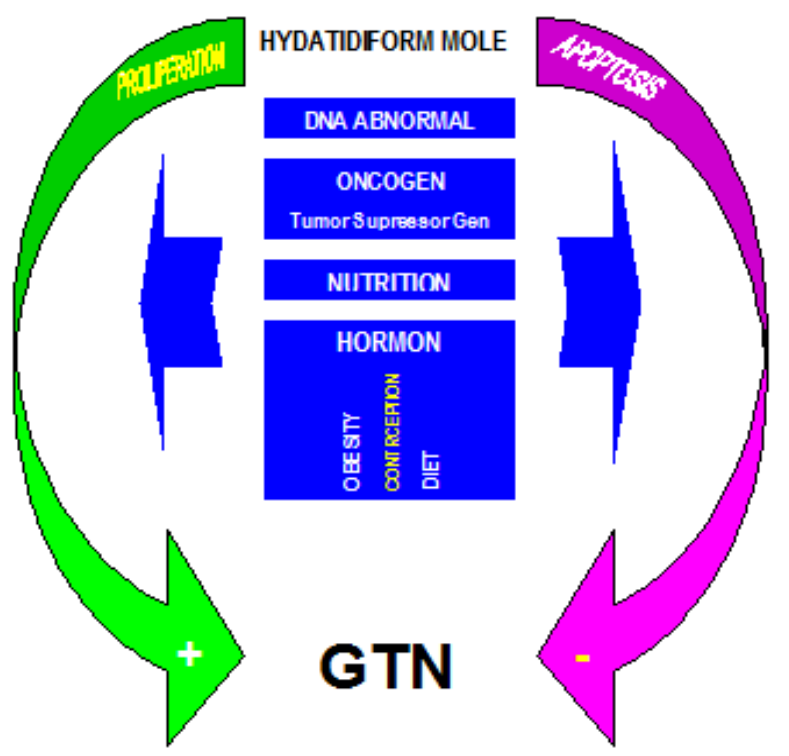

Fig.1. Factors in carcinogenesis GTN [6-11]

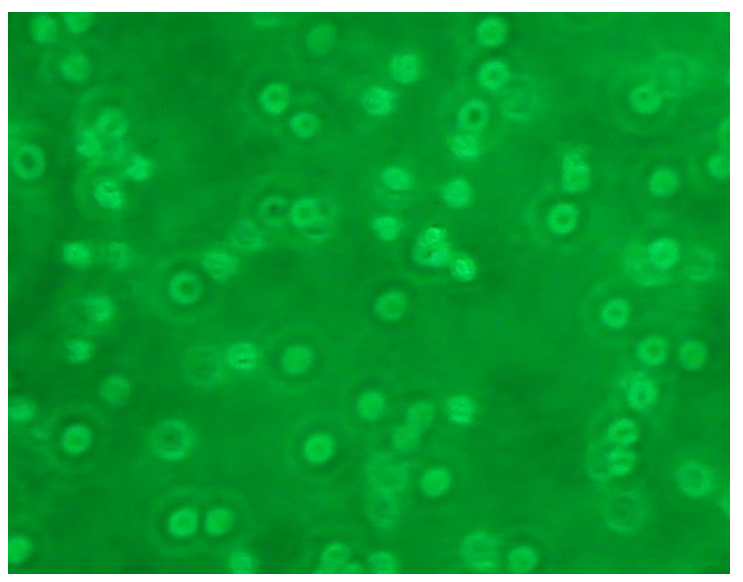

Fig.2. Good quality trophoblast cell culture examined by Green-light microscopy (Magnification 40x)

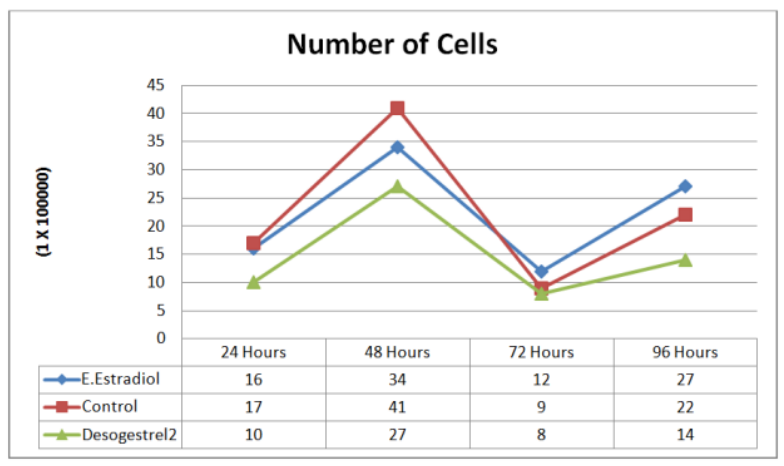

Fig.3. The number of trophoblast cells 


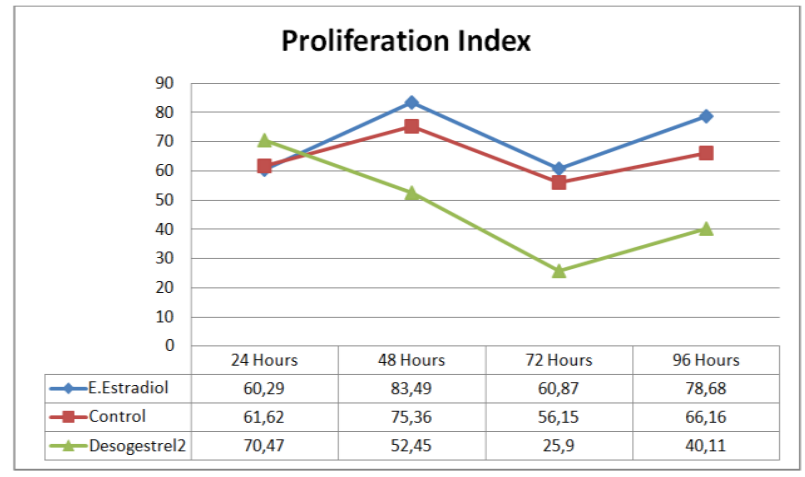

Fig.4. Proliferation Index of trophoblast cells

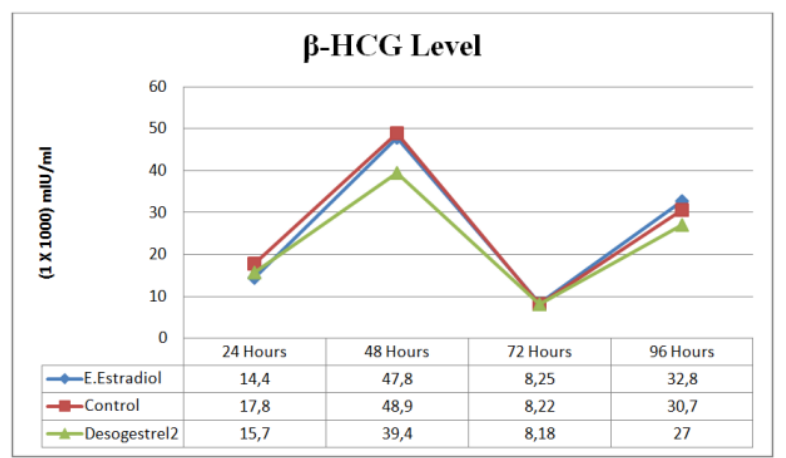

Fig.5. $\beta$-HCG Level of trophoblast cells

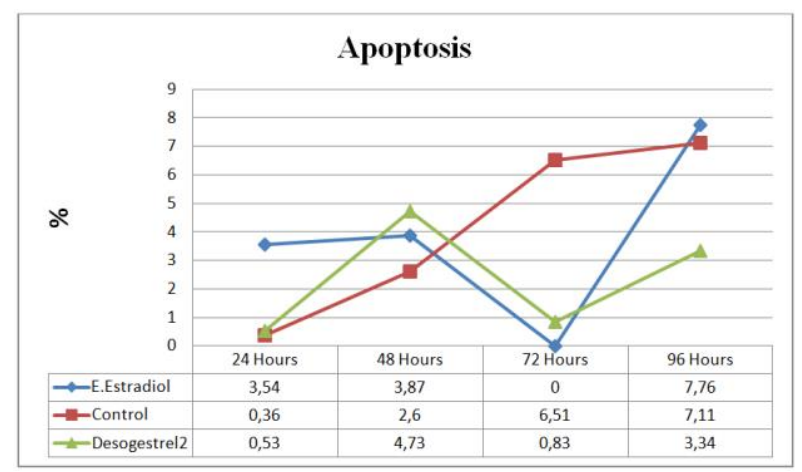

Fig.6. Apoptosis of trophoblast cells

\section{Discussion}

The effect of estradiol on carcinogenesis as well as the influence of estradiol on cell proliferation has been demonstrated in some organ cells. Estradiol will increase the activity of cell proliferation, but the effect of estradiol and progesterone on proliferation and apoptosis of cells is not a simple mechanism and the only one factor, but also influenced by other factors such as growth factors and the presence or absence of estrogen or progesterone receptors on these cells. This study is limited to explore hormonal factors ethynil estradiol and desogestrel. This study didn't prove the role of growth factrors and receptors on trophoblast cells. This study is expected to to give information about the effect of ethynil estradiol and desogestrel on hydatidiform mole trophoblast cells. Preliminary data and this procedure experience is expected to be used for future research. The result of this study proved that ethynil estradiol will increase hydatidiform mole trophoblast cells proliferation. These result are consistent with previous studies done on breast cells, endometrial cells and uterine leiomyoma cells.

Yager JD and Zivadinovic D in different research have proven that estradiol will increase the proliferation of cell lines MCF-7 breast cancer. The mechanism of estradiol may increase cell proliferation as follows. Estradiol affect cell proliferation through both estrogen receptor in the cell membrane, in the 
cytoplasm of cells as well as in the cell nucleus. Furthermore estradiol-receptor complex in the cytoplasm of cells will activate the gene in mitochondria and estradiol receptor complex in the cell nucleus to activate genes through the cell nucleus estrogen receptor element (ERE) found in the gene. Estradiolreceptor complexes in the cell membrane will pass the signal through two transduction signal pathways: (a) adenyl cyclase which increase cAMP through the protein kinase-A. (b) transduction signal pathways passed through Ras, Raf, MEK 1/2, ERK 1/2. Furthermore, estradiol through (mitogen -activated protein kinase) and (phosphatidylinositol-3 kinase) will increase the proliferation and apoptosis cells [18-20].

The result of this study found that desogestrel will inhibit proliferation of hydatidiform mole trophoblast cells. These result are consistent with research conducted by Tong $\mathrm{W}$, which has proven that progesterone inhibits uterine epithelial cells proliferation [21].

The mechanism of progesterone that inhibit cell proliferation is as follows. Progesterone inhibits the estrogen activity in inducing Cyclin D1 and CDK4 in the nucleus of cells. Progesterone will also activate the Cyclin E-CDK2 kinase and Cycline A. As it known that Cyclin D1, CDK4, Cyclin E, Cyclin A-CDK2 play a role in the cell cycle when the cell cycle G1 phase and will enter phase S. Progesterone in this case would inhibit the cell cycle at G1 phase in whice will enter S phase. Research on endometrial cells proved that progesteron would inhibit endometrial cell proliferation via insulin growth factor (IGF). High progesterone will increase IGF-binding protein 1 (IGFBP1), furthermore will decrease concentration IGF1. As it known IGF1 through IGF-1R can activate the RAS/RAF which will induce cell proliferation through PI3K [22].

This research is still can not conclude about effect of ethynil estradiol and desogestrel on trophoblast cell apoptosis. Yager JD has proved that estradiol will decrease the apoptosis of breast cancer cell, and Liu J also proved that progesterone will decrease the apoptosis of uterine leiomyoma cells [18,23]. Progesterone decrease the activity of cells apoptosis through progesterone receptors will interact with Bcl-2 gen promoter that will induce the expression of Bcl-2. As we known Bcl-2 is an anti-apoptotic gene that would inhibit the activity of apoptosis [24]. Receptor progesterone of trophoblast cells will inhibit apoptosis through down-regulation of the expression of Fas, FasL, caspase-8, caspase-3 and PARP [25,26].

This study cannot prove the effect of ethynil estradiol and desogestrel on apotosis hydatidiform mole trophoblast cells. this is a weaknesses of this study, of course it's need another next study with better design research. This study clearly prove about the influence of ethynil estradiol on proliferation of hydatidiform mole trophoblast cells. That prove from both cell proliferation and also cell produce $\beta$-HCG. This study clearly prove about the anti-proliferative effect of desogestrel on hydatidiform mole trophoblast cells. That prove from both lower proliferation and also lower producing $\beta$-HCG. Desogestrel is just one of many synthetic progesterone, we need new research on other types of progesterone such as levonorgestrel. We also need another design research that use combination both estrogen and progesterone in medium culture cells to know the balancing effect of both hormones in carcinogenesis. Hopefully, this research can provide benefits in the future.

\section{Conclusion}

Ethynil estradiol at concentration $10 \mathrm{nmol} / \mathrm{mL}$ will increase proliferation of hydatidiform mole trophoblast cell that characterized by increase of: cell prolifration index, number of cells and cell producing $\beta$-HCG. Desogestrel at concentration $100 \mathrm{nmol} / \mathrm{mL}$ decrease proliferation of hydatidiform mole trophoblast cells. There are no effect of ethynil estradiol and desogestrel on apoptosis of hydatidiform mole trophoblast cells.

\section{Conflict of interest}

No potential conflict of interest relevant to this article was reported.

\section{Acknowledgments}

We thank you for all staff at Laboratory of cell biology, Dharmais Cancer Center Hospital Jakarta Indonesia. 


\section{References}

1. Andrijono. Gestational Trophoblastic Neoplasia. Jakarta: Oncology Division Departement of Obstetric and Gynecology, 2007: 1-24

2. Andrijono, Muhilal M. Prevention of Post-Mole Malignant Trophoblastic Disease with VitaminA. Asian Pacific J Cancer Prev. 2010;11:567-570.

3. Steigrad SJ. Epidemiology of gestational trophoblastic diseases. Best Pract Res Clin Obstet Gynaecol 2003;17(6):837-47.

4. Soper JT, Mutch DG, Schink JC. Diagnosis and treatment of gestational trophoblastic disease: ACOG Practice Bulletin No. 53. Gynecol Oncol 2004;93(3):575-85.

5. Hextan Y.S. Ngan KKLC, Kar-Fai Tam. Gestational trophoblastic disease. Current Obstetrics \& Gynaecology 2006;16:93-99.

6. Parazzini F, Cipriani S, Mangili G, Garavaglia E, Guarnerio P, Ricci E, et al. Oral contraceptives and risk of gestational trophoblastic disease. Contraception 2002;65(6):425-7.

7. Palmer JR, Driscoll SG, Rosenberg L, Berkowitz RS, Lurain JR, Soper J, et al. Oral contraceptive use and risk of gestational trophoblastic tumors. $J$ Natl Cancer Inst 1999;91(7):635-40.

8. Costa HL, Doyle P. Influence of oral contraceptives in the development of post-molar trophoblastic neoplasia--a systematic review. Gynecol Oncol 2006;100(3):579-85.

9. Cibula D, Gompel A, Mueck AO, Vecchia C.La, Hannaford P.C, Skouby S.O, Zikan M, Dusek L. Hormonal contraception and risk of cancer. Human Reproduction Update 2010;16(6):63150.

10.Yager JD. Endogenous estrogens as carcinogens through metabolic activation. J Natl Cancer Inst Monogr 2000(27):67-73.

11.Inoue A, Seino Y, Terasaka S, Hayashi S, Yamori $\mathrm{T}$, Tanji $\mathrm{M}$, et al. Comparative profiling of the gene expression for estrogen responsiveness in cultured human cell lines. Toxicol In Vitro 2007;21(4):741-52.

12.Suga S, Kato K, Ohgami T, Yamayoshi A, Adachi S, Asanoma K, et al. An inhibitory effect on cell proliferation by blockage of the MAPK/estrogen receptor/MDM2 signal pathway in gynecologic cancer. Gynecol Oncol 2007;105(2):341-50.

13. Marquez-Garban DC, Chen HW, Fishbein MC, Goodglick L, Pietras RJ. Estrogen receptor signaling pathways in human non-small cell lung cancer. Steroids 2007;72(2):135-43.

14.Attalla H, Westberg JA, Andersson LC, Adlercreutz H, Makela TP. 2-Methoxyestradiolinduced phosphorylation of Bcl-2: uncoupling from JNK/SAPK activation. Biochem Biophys Res Commun 1998;247(3):616-9.

15.Birken S, Berger P, Bidart JM, Weber M, Bristow A, Norman R, et al. Preparation and characterization of new WHO reference reagents for human chorionic gonadotropin and metabolites. Clin Chem 2003;49(1):144-54.

16.Tuschl H, Schwab CE. The use of flow cytometric methods in acute and long-term in vitro testing. Toxicol In Vitro 2005;19(7):845-52.

17.He F, Yang Z, Tan Y, Yu N, Wang X, Yao N, et al. Effects of Notch ligand Delta1 on the proliferation and differentiation of human dental pulp stem cells in vitro. Arch Oral Biol 2009;54(3):216-22.

18.Yager JD, Davidson NE. Estrogen carcinogenesis in breast cancer. $N$ Engl J Med 2006;354(3):27082.

19.Zivadinovic D, Gametchu B, Watson CS. Membrane estrogen receptor-alpha levels in MCF-7 breast cancer cells predict cAMP and proliferation responses. Breast Cancer Res 2005;7(1):R101-12.

20.Wang Q, Li X, Wang L, Feng YH, Zeng R, Gorodeski G. Antiapoptotic effects of estrogen in normal and cancer human cervical epithelial cells. Endocrinology 2004;145(12):5568-79.

21.Tong W, Pollard JW. Progesterone inhibits estrogen-induced cyclin D1 and cdk4 nuclear translocation, cyclin E- and cyclin A-cdk2 kinase activation, and cell proliferation in uterine epithelial cells in mice. Mol Cell Biol $1999 ; 19(3): 2251-64$. 
22.Frost RA, Mazella J, Tseng L. Insulin-like growth factor binding protein-1 inhibits the mitogenic effect of insulin-like growth factors and progestins in human

23.Liu J, Matsuo H, Laoag-Fernandez JB, Xu Q, Maruo T. The effects of progesterone on apoptosis in the human trophoblast-derived HTR-8/SV neo cells. Mol Hum Reprod 2007;13(12):869-74.

24.Yin P, Lin $Z$, Cheng YH, Marsh EE, Utsunomiya $\mathrm{H}$, Ishikawa $\mathrm{H}$, et al. Progesterone receptor regulates Bcl-2 gene expression through direct binding to its promoter region in uterine leiomyoma cells. $J$ Clin Endocrinol Metab 2007;92(11):4459-66.

25. Maruo T, Matsuo H, Shimomura Y, Kurachi O, Gao Z, Nakago S, et al. Effects of progesterone on growth factor expression in human uterine leiomyoma. Steroids 2003;68(10-13):817-24.

26.Liu J, Matsuo H, Laoag-Fernandez JB, Xu Q, Maruo T. The effects of progesterone on apoptosis in the human trophoblast-derived HTR-8/SV neo cells. Mol Hum Reprod 2007;13(12):869-74. 